cardiovascular, a utilização da levobupivacaína como solução para bloqueios de plexo braquial parece ser bem indicada.

\section{Supraclavicular Brachial Plexus Block: A Comparative Clinical Study between Bupivacaine and Levobupivacaine}

José Ricardo Pinotti Pedro, TSA, M.D., Lígia Andrade Silva Telles Mathias, TSA, M.D., Judymara Lauzi Gozzani, TSA, M.D., Flavia Salles de Souza Pinotti Pedro, TSA, M.D., José Carlos Rittes, TSA, M.D.

\section{INTRODUCTION}

Scientific confirmation of the cardiac toxicity of bupivacaine in the $1980 \mathrm{~s}^{1-4}$ stimulated experimental studies with its enantiomers, which indicated lower cardiodepressor activity of $\mathrm{S}(-)$ bupivacaine (levobupivacaine $)^{5-8}$.

Several clinical studies on neuroaxis block have shown that the efficacy and the duration of the motor blockade of levobupivacaine are similar to that of racemic bupivacaine ${ }^{9-}$ ${ }^{12}$, while others observed that the duration of its motor blockade is shorter than that of racemic bupivacaine ${ }^{13-16}$.

Subclavian perivascular block is widely used in several upper limb procedures. One can choose several approaches whose common denominator is the larger volume of local anesthetics required, comparing with neuroaxis blocks, and making the choice of the local anesthetic crucial. The use of levobupivacaine in brachial plexus block seems promising considering the lower toxicity and the need of large volumes. However, the possibility of unsatisfactory motor blockade, both in neuroaxis and brachial plexus blocks, has yet to be discarded ${ }^{17-24}$. This lack of consensus was the basis for this study, i.e., whether the motor and sensorial blockade of levobupivacaine in brachial plexus block is comparable to that of bupivacaine. The primary objectives of the present study included comparing the latency and prevalence of failure of the motor blockade of racemic bupivacaine and levobupivacaine in subclavian perivascular brachial plexus block. Secondary objectives included the evaluation of the effectivity of the motor and sensorial blockades, the degree of the motor blockade, and the presence of adverse events.

\section{METHODS}

After approval by the Ethics Committee of the Irmandade Santa Casa de Misericórdia de São Paulo, 50 patients undergoing surgical procedures of the shoulder and arm were included in this transversal double-blind study. Inclusion criteria were as follows: physical status I and II according to the ASA (American Society of Anesthesiologists) classification; ages between 18 and 55years; and patients with bone or soft tissue lesions of the shoulders and arms. Patients with coagulation disorders, severe cardiopathies, liver disease, and kidney diseases, neurologic disorders or deficit, associated peripheral nerve lesions, skin lesion at the site of the blockade, or associated lesions in other areas of the body requiring general anesthesia, as well as pregnant women or those suspected of being pregnant, were excluded from the study.

Patients were assigned according to an increasing numeric sequence that classified the local anesthetic provided by the laboratory. The local anesthetic $(0.5 \%$ bupivacaine or levobupivacaine) was provided in non-identified, numbered, 30- $\mathrm{mL}$ ampoules. The numeric sequence was generated by a random list created by the laboratory that provided the local anesthetic for the study.

According to this method, two groups of 25-patient were created: Bupi group $\left(\mathrm{B}_{\text {BUP }}\right)-30 \mathrm{~mL}$ of $0.5 \%$ bupivacaine, and Levo group $\left(G_{L E V O}\right)-30 \mathrm{~mL}$ of $0.5 \%$ levobupivacaine.

On the day before the surgery, patients were informed about the study and signed an informed consent. Patients did not receive any pre-medication.

In the operating room, venoclysis was performed in the contralateral upper limb, Ringer's lactate $10 \mathrm{~mL} . \mathrm{kg}^{-1}$ was infused, and monitoring included heart rate, electrocardiogram, noninvasive blood pressure, and peripheral oxygen saturation. Patients were placed on the supine position with the head turned slightly away from the side to be blocked, and the arm placed alongside the body; the subclavian perivascular technique described by Kulenkampff, modified by Winnie \& Collins in $1964^{25}$, was performed. The brachial plexus was identified by a peripheral neurostimulator (Stimuplex ${ }^{\oplus}, B$ Braun) with 2- $\mathrm{Hz}$ and $1.0-\mathrm{mA}$. The site that triggered muscular response to a stimulus equal to or lower than $0.4 \mathrm{~mA}$ was identified, and $30 \mathrm{~mL}$ of the local anesthetic were administered.

Sensorial blockade was evaluated by pinprick stimulation of $\mathrm{C}_{5}, \mathrm{C}_{6}, \mathrm{C}_{7}$, and $\mathrm{C}_{8}$ metameres $1,2,5,10,15,20,25$, and 30 minutes after the administration of the local anesthetic and every five minutes until the effectivity or failure of the blockade was identified. Failure of blockade was diagnosed if sensorial or motor change was not observed up to 45 minutes after the administration of the local anesthetic. Motor blockade was evaluated by flexion of the $5^{\text {th }}$ finger, thumb adduction, extension, abduction, and flexion of the wrist, pronation of the forearm, and rotation and abduction of the humerus. The time between the administration of the local anesthetic and the onset of the blockade for each of the movements mentioned was recorded. To assess the degree of the motor blockade, the following classification was used: 1) without paralysis; 2) difficulties raising the arm and weakness of the hand; and 3) unable to raise the arm. In case of failure, the patient underwent general anesthesia and the procedure was carried out. Those cases were maintained in the study and analyzed as blockade failures. 
After establishment of the blockade, sedation was supplemented with sequential intravenous boluses of $1 \mathrm{mg}$ of midazolam, and patients remained in horizontal dorsal decubitus with oxygen via nasal catheter. At the end of the procedure, patients were transferred to the post-anesthetic care unit.

Parameters analyzed included: age, weight, height, gender, physical status according to the ASA classification; duration of the surgical procedure; latency and incidence of failure of sensorial and motor blockades; and degree of motor blockade.

The primary outcome of the study included the latency and prevalence of motor blockade failures. It was calculated that at least 20 patients were necessary in each group to detect a 5-minute difference in the latency of the motor blockade with type I $(\alpha)$ error of 0.05 , and type II error $(\beta)$ of 0,80 .

Anthropometric data underwent descriptive analysis and, according to the parameter, the following tests were used: non-paired $t$ test (age, weight, and height); Fisher's exact test (gender, physical status, and incidence of sensorial and motor blockade failures); Mann-Whitney test (latency of the sensorial and motor blockades, and duration of the surgical procedure); Chi-square test (degree of motor blockade).

The statistical tests used are an integral part of the SPSS for Windows 10 software.

\section{RESULTS}

Significant differences in anthropometric data and physical status were not observed between both groups (Table I), demonstrating that the study groups were comparable.
Table I - Demographic Data and Descriptive Level of the Statistical Tests

\begin{tabular}{lccc}
\hline Parameters & $\mathrm{G}_{\text {BUPI }}$ & $\mathrm{G}_{\text {LEVO }}$ & $\mathrm{p}$ \\
\hline Age (years) ${ }^{*}$ & $33.6 \pm 11.2$ & $35.9 \pm 10.6$ & $0.5011 \#$ \\
Weight $(\mathrm{kg}){ }^{*}$ & $64.3 \pm 13.4$ & $64.8 \pm 13.6$ & $0.9122 \#$ \\
Height $(\mathrm{cm}){ }^{*}$ & $164 \pm 9.7$ & $166 \pm 12.1$ & $0.6787 \#$ \\
Gender (M/F) & $17 / 8$ & $16 / 9$ & $0.5175^{* *}$ \\
Physical status ASA (I/II) & $19 / 6$ & $20 / 5$ & $0.6175^{* *}$ \\
\hline
\end{tabular}

*Data expressed as Mean \pm SD

$\mathrm{G}_{\text {BUPI }}=$ racemic bupivacaine; $\mathrm{G}_{\mathrm{LEVO}}=$ levobupivacaine

\#Descriptive level of non-paired $t$ test; ${ }^{* *}$ descriptive level of Fisher's exact test

The duration of the surgery (median) was 32.5 and 35.0 minutes in $G_{\text {BUPI }}$ and $G_{\text {LEVO }}$, respectively, but this difference was not statistically significant ( $p=0.7242$ - Mann-Whitney test). The latency and incidence of failures were not statistically different between both groups (Table II). The incidence of grades 1, 2, and 3 motor blockade was also similar in the study groups ( $p=0.8723$ ), and the incidence of grade 3 motor blockade in both groups was $76.0 \%$ (Table III).

The latency of the sensorial blockade in $\mathrm{C}_{5}, \mathrm{C}_{6}, \mathrm{C}_{7}$, and $\mathrm{C}_{8}$ metameres did not show normal distribution; therefore, median and $25^{\text {th }}$ and $75^{\text {th }}$ percentiles were used in the respective statistical analyses. Comparing the latency of the sensorial blockade, statistical differences were observed between both groups in $\mathrm{C}_{5}, \mathrm{C}_{6}, \mathrm{C}_{7}$, and $\mathrm{C}_{8}$, with shorter latency in $\mathrm{G}_{\mathrm{LEVO}}$.

Table II - Latency of the Motor Blockade, Failure Rate, and Descriptive Level of the Statistical Tests

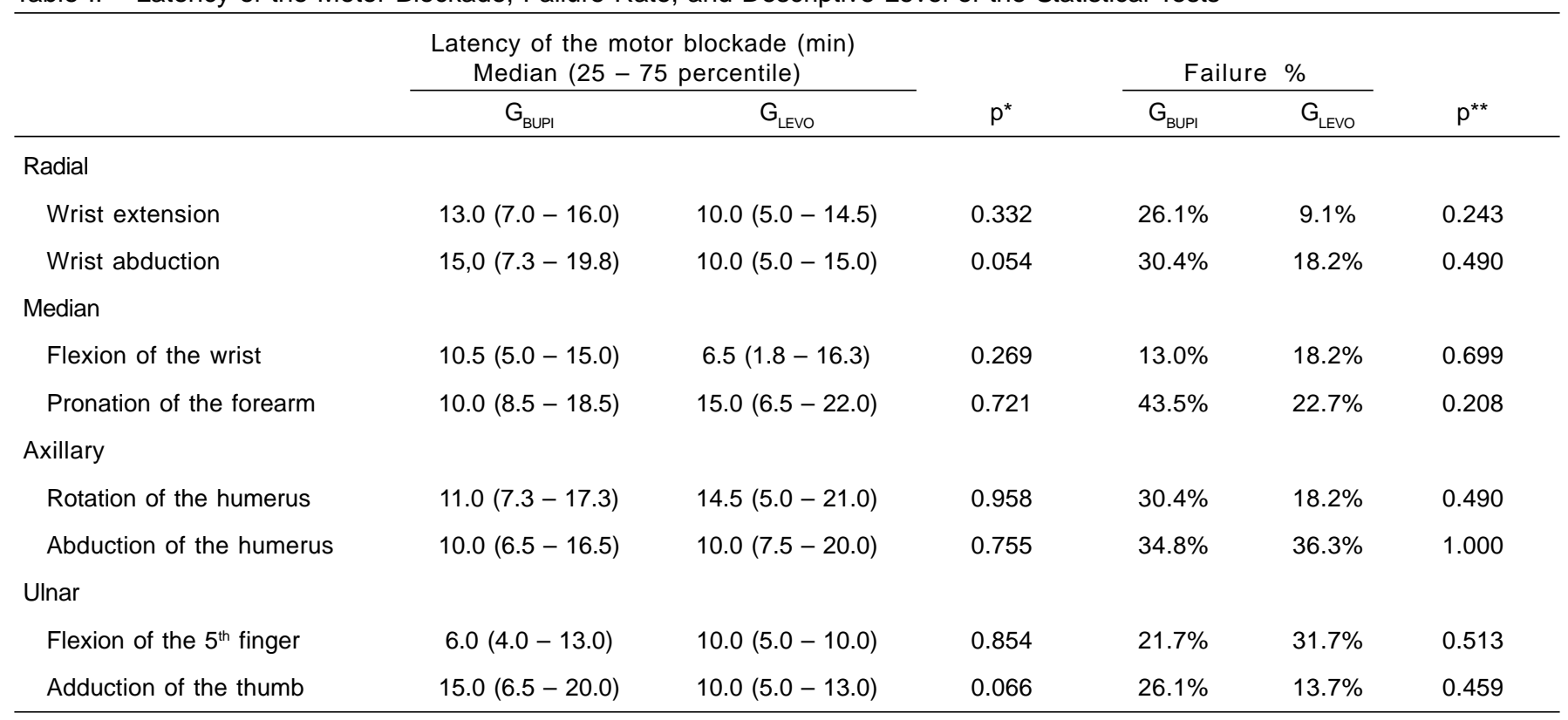

$\mathrm{p}^{*}=$ descriptive level of the Mann-Whitney test; $\mathrm{p}^{* *}=$ descriptive level of Fisher's exact test

$\mathrm{G}_{\mathrm{BUPI}}=$ racemic bupivacaine; $\mathrm{G}_{\mathrm{LEVO}}=$ levobupivacaine 
Table III - Evaluation of the Degree of the Motor Blockade

\begin{tabular}{lcc}
\hline & $\mathrm{G}_{\text {BUPI }}$ & $\mathrm{G}_{\text {LEVO }}$ \\
\hline Without paralysis & $2(8.0 \%)$ & $1(4.0 \%)$ \\
$\begin{array}{l}\text { Difficulty raising the arm and } \\
\text { hand weakness }\end{array}$ & $4(16.0 \%)$ & $5(20.0 \%)$ \\
$\begin{array}{l}\text { Unable to raise the arm } \\
\text { ynd }\end{array}$ & $19(76.0 \%)$ & $19(76.0 \%)$ \\
\hline
\end{tabular}

$p=0.8723-$ descriptive level of the Chi-square test

$\mathrm{G}_{\mathrm{BUPI}}=$ racemic bupivacaine; $\mathrm{G}_{\mathrm{LEVO}}=$ levobupivacaine
However, statistical differences in the incidence of failures in the four metameres analyzed were not observed (Table IV). Significant hemodynamic changes were not observed. As for adverse events, one case of tinnitus, without deleterious consequences, was observed in each group.

Table IV - Latency of the Sensorial Blockade, Failure Rate, and Descriptive Level of the Statistical Tests

\begin{tabular}{|c|c|c|c|c|c|c|}
\hline & \multicolumn{2}{|c|}{ Latency of the sensorial blockade (min) \# } & \multirow[b]{2}{*}{$\mathrm{p}^{*}$} & \multicolumn{2}{|c|}{ Failures \% } & \multirow[b]{2}{*}{$\mathrm{p}^{* *}$} \\
\hline & $G_{\text {BUPI }}$ & $\mathrm{G}_{\text {LEVO }}$ & & $\mathrm{G}_{\text {BUPI }}$ & $\mathrm{G}_{\text {LEVO }}$ & \\
\hline $\mathrm{C}_{5}$ & $10.0(5.0-15.0)$ & $5.0(3.0-14.0)$ & 0.048 & $13.0 \%$ & $14.0 \%$ & 1.000 \\
\hline $\mathrm{C}_{6}$ & $8.0(5.5-14.5)$ & $5.0(1.0-8.8)$ & 0.005 & $9.0 \%$ & $9.0 \%$ & 1.000 \\
\hline $\mathrm{C}_{7}$ & $8.0(5.0-15.0)$ & $5.0(1.0-10.0)$ & 0.010 & $9.0 \%$ & $14.0 \%$ & 1.000 \\
\hline $\mathrm{C}_{8}$ & $9.5(5.0-14.0)$ & $5.0(3.0-10.0)$ & 0.048 & $13.0 \%$ & $14.0 \%$ & 1.000 \\
\hline
\end{tabular}

\#Median (25 - 75 percentile); $\mathrm{p}^{*}=$ Mann-Whitney test; $\mathrm{p}^{\star *}=$ Fisher's test

$\mathrm{G}_{\mathrm{BUPI}}=$ racemic bupivacaine; $\mathrm{G}_{\mathrm{LEVO}}=$ levobupivacaine

\section{DISCUSSION}

The present study demonstrated that the anesthetic qualities of pure levorotatory bupivacaine in brachial plexus block are similar to that of the racemic mixture.

Brachial plexus block has long been considered a safe method when proper technique is observed, which includes monitoring and patient selection. However, brachial plexus blockade can set a potential place for absorption of local anesthetics and the development of systemic toxicity ${ }^{26}$. A considerable number of studies on the use of levobupivacaine in subarachnoid blocks and, especially, in epidural blocks can be found in the literature. But the same is not true for levobupivacaine in brachial plexus blocks ${ }^{17,19,20-24,27}$. Only two studies compared racemic bupivacaine and levobupivacaine $^{17,21}$ while the other studies in the literature compared levobupivacaine and ropivacaine ${ }^{19,20}$ or evaluated different volumes, doses, concentrations, and routes of administration of levobupivacaine 18,22-24. $^{\text {. }}$

In the present study, shorter latency of the sensorial blockade was observed in the levobupivacaine group in all metameres evaluated, but both groups had similar incidence of failures. However, Cox et al. ${ }^{17}$ evaluated the dose of $0.4 \mathrm{mg} . \mathrm{kg}^{-1}$ of $0.25 \%$ and $0.5 \%$ levobupivacaine and $0.5 \%$ racemic bupivacaine in patients undergoing elective hand surgeries, and they did not observed statistically significant differences in the latency of the sensorial blockade between the groups.

In the study of Liisanatti et al. ${ }^{21}$ on axillary brachial plexus block with $45 \mathrm{~mL}$ of local anesthetic $(0.5 \%$ levobupivacaine, $0.5 \%$ ropivacaine, or $0.5 \%$ racemic bupivacaine) without epinephrine, the authors observed that the latency of the sensorial blockade was similar in the three groups, but the degree of the sensorial blockade was greater in the ropivacaine and bupivacaine groups than in the levobupivacaine groups.

In the present study, statistically significant differences in motor blockade (latency, degree of the blockade, and failure rates) were not observed between both groups, corroborating the results of Cox et al. ${ }^{17}$, but partly disagreeing with the results of Liisanantti et al. ${ }^{21}$ Those authors also observed similar latency of the motor blockade in the three studied groups, but they analyzed the motor blockade of the shoulder and hand separately and observed that the degree of the motor blockade in the shoulder was greater in the ropivacaine group, followed by bupivacaine and levobupivacaine. The motor blockade in the hand did not show statistically significant differences. Since the present study used the supraclavicular technique while the axillary approach was used by Liisanantti et al. ${ }^{21}$, this might be one of the reasons for the differences in the results.

The clinical results of levobupivacaine in brachial plexus blocks, both in the present study and in the literature, indicate that latency, duration, and quality of the blockade is similar to that of racemic bupivacaine. Considering the greater toxicity potential and the cardiovascular effects of the racemic mixture, levobupivacaine seems a good indication for brachial plexus blocks. 


\section{REFERÊNCIAS - REFERENCES}

01. Clarkson CW, Hondeghem LM - Mechanism for bupivacaine depression of cardiac conduction: fast block of sodium channels during the action potential with slow recovery from block during diastole. Anesthesiology, 1985;62:396-405.

02. Bernards CM, Carpenter RL, Kenter ME et al. - Effect of epinephrine on central nervous system and cardiovascular system toxicity of bupivacaine in pigs. Anesthesiology, 1989; 71:711-717.

03. Feldman HS, Arthur GR, Covino BG - Comparative systemic toxicity of convulsant and supraconvulsant doses of intravenous ropivacaine, bupivacaine and lidocaine in the conscious dog. Anesth Analg, 1989;69:794-801.

04. Mazoit JX, Boico O, Samii K - Myocardial uptake of bupivacaine: II. Pharmacokinetics and pharmacodynamics of bupivacaine enantiomers in the isolated perfused rabbit heart. Anesth Analg, 1993;77:477-482.

05. Simonetti MPB, Batista RA, Ferreira FMC - Estereoisomeria: a interface da tecnologia industrial de medicamentos e da racionalização terapêutica. Rev Bras Anestesiol, 1998;48:390-399.

06. Santos AC, DeArmas PI - Systemic toxicity of levobupivacaine, bupivacaine and ropivacaine during continuous intravenous infusion to nonpregnant and pregnant ewes. Anesthesiology, 2001;95:1256-1264.

07. Ohmura S, Kawada M, Ohta T et al. - Systemic toxicity and resuscitation in bupivacaine-, levobupivacaine-, or ropivacaineinfused rats. Anesth Analg, 2001;93:743-748.

08. Gristwood RW - Cardiac and CNS toxicity of levobupivacaine: strengths of evidence for advantage over bupivacaine. Drug Saf, 2002;25:153-163

09. Tanaka PP, Ogleari M, Valmorbida et al. - Estudo comparativo entre soluções a $0,5 \%$ de levobupivacaína, bupivacaína em excesso enantiomérico de $50 \%$ e bupivacaína racêmica em anestesia peridural para cirurgia de abdômen inferior. Rev Bras Anestesiol, 2005;55:597-605.

10. Koch T, Fichtner A, Schwemmer U et al. - Levobupivacaine for epidural anaesthesia and postoperative analgesia in hip surgery: a multi-center efficacy and safety equivalence study with bupivacaine and ropivacaine. Anaesthesist, 2008;57:475482.

11. Luck JF, Fettes PD, Wildsmith JA - Spinal anaesthesia for elective surgery: a comparison of hyperbaric solutions of racemic bupivacaine, levobupivacaine, and ropivacaine. $\mathrm{Br} \mathrm{J}$ Anaesth 2008;10:705-710.

12. Mantouvalou M, Ralli S, Arnaoutoglou H et al. - Spinal anesthesia: comparison of plain ropivacaine, bupivacaine and levobupivacaine for lower abdominal surgery. Acta Anaesthesiol Belg, 2008;59:65-71.

13. De Negri P, Ivani G, Tirri T et al. - A comparison of epidural bupivacaine, levobupivacaine, and ropivacaine on postoperative analgesia and motor blockade. Anesth Analg, 2004;99:45-48.

14. Beilin Y, Guinn NR, Bernstein $\mathrm{HH}$ et al. - Local anesthetics and mode of delivery: bupivacaine versus ropivacaine versus levobupivacaine. Anesth Analg, 2007;105:756-763.

15. Camorcia M, Capogna G, Berritta $C$ et al. - The relative potencies for motor block after intrathecal ropivacaine, levobupivacaine, and bupivacaine. Anesth Analg, 2007;104:904-907.

16. Lacassie HJ, Habib AS, Lacassie HP et al. - Motor blocking minimum local anesthetic concentrations of bupivacaine, levobupivacaine, and ropivacaine in labor. Reg Anesth Pain Med, 2007;32:323-329.

17. Cox CR, Checketts MR, Mackenzie N et al. - Comparison of S(-)bupivacaine with racemic (RS)-bupivacaine in supraclavicular brachial plexus block. Br J Anesth, 1998;80:594-598.
18. Crews JC, James RL - 0,5\% Levobupivacaine for axillary plexus anaesthesia: efficacy, safety, pharmacokinetics. Eur J Anaesthesiol, 2000;17:100-109.

19. Casati A, Borghi B, Fanelli G et al. - Interscalene brachial plexus anesthesia and analgesia for open shoulder surgery: a randomized, double-blinded comparison between levobupivacaine and ropivacaine. Anesth Analg, 2003;96:253-259.

20. Cline E, Franz D, Polley RD et al. - Analgesia and effectiveness of levobupivacaine compared with ropivacaine in patients undergoing an axillary brachial plexus block. AANA J, 2004;72: 339-345.

21. Liisanantti O, Luukkonen J, Rosenberg PH - High-dose bupivacaine, levobupivacaine and ropivacaine in axillary brachial plexus block. Acta Anaesthesiol Scand, 2004;48:601-606.

22. Nuñez Aguado D, López Alvarez S, Salamanca Montaña ME et al. - Bloqueo del plexo braquial a nivel humeral con levobupivacaina: estúdio comparativo alta concentración/pequeiio volumen frente a baja concentración/alto volumen. Rev Esp Anestesiol Reanim, 2005;52:529-535.

23. Kean J, Wigderowitz CA, Coventry DM - Continuous interscalene infusion and single injection using levobupivacaine for analgesia after surgery of the shoulder. A double-blind, randomised controlled trial. J Bone Joint Surg Br, 2006;88:1173-1177.

24. Zhao X, Wang YW, Chen $\mathrm{H}$ et al. - Efficacy of low dose levobupivacaine $(0.1 \%)$ for axillary plexus block using multiple nerve stimulation. Anaesth Intensive Care, 2008;36:850-854.

25. Winnie AP, Collins VJ - The subclavian perivascular technique of brachial plexus anesthesia. Anesthesiology, 1964;25:353-363.

26. Liu SS, Hodgson PS - Local Anesthetics, em: Barash PG, Cullen BF, Stoelting RK -Clinical Anesthesia, $4^{\text {th }}$, Philadelphia, Lippincott Williams \& Wilkins, 2001;449-469.

27. Crews JC, Weller RS, Moss $\mathrm{J}$ et al - Levobupivacaine for axillary brachial plexus block: a pharmacokinetic and clinical comparison in patients with normal renal function or renal disease. Anesth Analg, 2002;95:219-223.

\section{RESUMEN}

Pedro JRP, Mathias LAST, Gozzani JL, Pedro FSSP, Rittes JC Bloqueo del Plexo Braquial por Vía Supraclavicular: Estudio Clínico Comparativo entre Bupivacaína y Levobupivacaína.

JUSTIFICATIVA Y OBJETIVOS: El bloqueo de plexo braquial es la técnica anestésica utilizada para procedimientos en miembros superiores. El plexo braquial es el territorio potencial para la absorción de anestésicos locales. Estudios de los estereoisómeros de la bupivacaína han venido demostrando un menor potencial de toxicidad de la fracción levógira (levobupivacaína), sobre el sistema cardiovascular. Sin embargo, se discute la eficacia anestésica (bloqueo sensitivo y motor), de la levobupivacaína en anestesia del neuro eje. Este estudio pretende demostrar la eficacia anestésica de la levobupivacaína, comparándola con la bupivacaína racémica en bloqueo de plexo braquial por la vía perivascular subclavia.

MÉTODO: Cincuenta pacientes adultos de ambos sexos, ASA I y II, fueron sometidos a la anestesia de plexo braquial vía perivascular subclavia para procedimientos ortopédicos de miembros superiores con la ayuda de un neuroestimulador. Se dividieron de modo aleatorio, en dos grupos: $G_{B U P I}$ - bupivacaína racémica, $G_{L E V O}$ - levobupivacaína, en un volumen de $30 \mathrm{~mL}$ a $0,5 \%$. El bloqueo sensitivo fue evaluado por el método de "picada de aguja" en los metámeros de $C_{5}$ a $C_{8}$; y el bloqueo motor, en los intervalos en minutos: $1,2,5,10,15,20,25,30$, o hasta la 
instalación del bloqueo en los movimientos de los dedos, la mano el antebrazo y el brazo.

RESULTADOS: No hubo ninguna diferencia estadística entre los dos grupos en cuanto a la latencia, incidencia de fallas, grado del bloqueo motor e incidencia de fallas y grado del bloqueo motor e incidencia de fallas del bloqueo sensitivo, pero sí que se verificó la diferencia estadística de la latencia del bloqueo sensitivo en todos los metámeros analizados. No hubo efectos adversos inherentes a la aplicación del anestésico local.

CONCLUSIONES: La levobupivacaína demostró una eficacia anestésica en el bloqueo de plexo braquial, igualable a la solución racémica usualmente utilizada. 